Eur. J. Clin. Chem. Clin. Biochem.

Vol. 31, 1993, pp. 725-731

(C) 1993 Walter de Gruyter \& Co. Berlin - New York

\title{
Oxidative Modification of Low Density Lipoproteins by Human Polymorphonuclear Leukocytes
}

\author{
By E. Wieland, A. Brandes ${ }^{1}$ ), V.W. Armstrong and M. Oellerich \\ Abteilung Klinische Chemie, Zentrum Innere Medizin, Georg-August-Universität Göttingen, Göttingen, Germany
}

(Received April 7/August 12, 1993)

\begin{abstract}
Summary: Oxidatively modified low density lipoproteins are thought to play an important role in the generation of macrophage-derived foam cells in early atherosclerotic lesions. Cultured endothelial cells, monocytes, macrophages and smooth muscle cells can modify low density lipoproteins, either by a free radical mechanism or by the action of lipoxygenases. Previous studies demonstrated that activated human polymorphonuclear leukocytes can oxidize low density lipoprotein lipids. Stimulation of the cells with phorbol 12-myristate 13acetate resulted in an increase both in superoxide anion production and in low density lipoprotein oxidation. The present results show that the oxidative modification of low density lipoproteins by human polymorphonuclear leukocytes can be inhibited by superoxide dismutase but not by the lipoxygenase inhibitor, $(5,8,11,14)$ eicosatetraynoic acid. The low density lipoproteins oxidized by polymorphonuclear leukocytes were recognized by the scavenger receptor of macrophages (P 388 cell line). It is proposed that the superoxide anion is an important factor in the the oxidative modification of low density lipoproteins induced by polymorphonuclear leukocytes, and that under conditions of increased oxidative metabolism in vivo, polymorphonuclear leukocytes can contribute to foam cell formation by a scavenger receptor-dependent process at lesion sites.
\end{abstract}

\section{Introduction}

The pathogenesis of atherosclerosis is complex and multifactorial. Hypercholesterolaemia is widely accepted as one of the major risk factors contributing to the development of coronary heart disease. From epidemiological studies $(1,2)$ and animal experiments $(3,4)$ it is clear that cholesterol is deposited in atherosclerotic plaques and that this cholesterol is mainly derived from plasma low density lipoproteins $(5,6)$. Recent evidence suggests an important role for the oxidative modification of low density lipoproteins in the pathogenesis of atherosclerosis. Incubation of low density lipoproteins with various cells such as endothelial cells, macrophages, human monocytes, and smooth muscle cells leads to an oxidatively modified form which is recognized by the scavenger receptor of macrophages, thus inducing foam cell formation (7). This type of modification is characterized by the

\footnotetext{
1) This work is part of the doctoral thesis of A. Brandes.
}

peroxidation of low density lipoprotein lipids and the modification of the apolipoprotein $\mathrm{B}-100$ by lipid peroxidation products $(8,9)$. It has been proposed that the oxidative modification of low density lipoproteins by cells can be mediated either by superoxide anions (10), or by the action of the 15-lipoxygenase enzyme $(11,12)$.

Leukocytes, both polymorphonuclear neutrophil leukocytes and monocytes, have been observed in the earliest atherosclerotic lesions $(13,14)$. When they encounter an appropriate ligand, these cells generate highly unstable oxygen species such as superoxide anions, hydrogen peroxide, hydroxyl radicals, and singlet oxygen (15). Increased leukocyte oxidative metabolism has been observed in hyperlipidaemic patients (16), and human polymorphonuclear leukocytes are known to stimulate peroxidation of low density lipoprotein lipids, as measured by the formation of thiobarbituric acid reactive substances and lipid hydroperoxides $(17,18)$. However, polymorphonuclear 
leukocytes also contain the 15-lipoxygenase enzyme (19). Modification of the apolipoprotein B-100 by neutrophil elastase has also been reported and it was suggested that such elastase-modified low density lipoproteins may contribute to foam cell formation (20). However, these elastase-modified low density lipoproteins are recognized by the low density lipoprotein receptor and not by the scavenger receptor of macrophages.

The present study was designed to clarify the mechanism of the oxidative modification of low density lipoproteins by polymorphonuclear leukocytes and to determine whether such modified low density lipoproteins are recognized by the scavenger receptor of macrophages.

\section{Materials and Methods}

\section{Preparation of cells}

Human polymorphonuclear leukocytes were isolated by density gradient centrifugation (21) using a $4+1$ (by vol.) mixture of neutrophil isolation medium (NIM; Los Alamos Diagnostics, Los Alamos, NM, USA) and Lymphoprep (Nycomed, Oslo, Norway). Five ml venous blood anticoagulated with $10000 \mathrm{U} / \mathrm{l}$ $\mathrm{Na}$-heparin were layered over an equal volume of the NIM/ Lymphoprep mixture in sterile plastic tubes and centrifuged at $400 \mathrm{~g}$ for $40 \mathrm{~min}$ at $4{ }^{\circ} \mathrm{C}$. Polymorphonuclear leukocytes were removed by aspiration and washed 3 times with Hank's Balanced Salt Solution (GIBCO, Paisley, UK). After the last wash erythrocytes were lysed for 30-60 seconds with $\mathrm{H}_{2} \mathrm{O}$ and the polymorphonuclear leukocyte suspension was washed again with Hank's Balanced Salt Solution. The resulting pellet was resuspended in serum-free Ham's F-10 medium (GIBCO, Paisley, UK) containing $100 \times 10^{3} \mathrm{U} / 1$ penicillin and $100 \mathrm{mg} / \mathrm{l}$ streptomycin. Cell numbers and purity were determined with an automatic cell counter (Technicon H 1, Bayer Diagnostic Co, Tarrytown, NY, USA) using the differential counting mode. Cell preparations contained $98 \%$ polymorphonuclear leukocytes, $2 \%$ lymphocytes, but no contamination by monocytes. Unless indicated otherwise, cell numbers were adjusted to $3 \times 10^{9} / 1$ and plated in serum-free Ham's F-10 medium (GIBCO, Paisley, UK) on $35 \mathrm{~mm}$ plastic cell culture dishes (Nunc, Roskilde, DK). Cells were allowed to settle for $15 \mathrm{~min}$, then used for modification studies without further washing.

For degradation experiments the murine macrophage cell line P 388 D (Paesel-Lorey GmbH, Frankfurt, Germany) was used. Cells were plated on $35 \mathrm{~mm}$ culture dishes in RPMI 1640 medium (GIBCO, Paisley, UK) containing fetal calf serum (volume fraction 0.1$)$ and antibiotics $\left(100 \times 10^{3} \mathrm{U} / \mathrm{l}\right.$ penicillin, $100 \mathrm{mg} / \mathrm{l}$ streptomycin). At confluence, cells were washed twice with serum-free RPMI 1640 medium, then used for degradation studies with low density lipoproteins.

Isolation and modification of low density lipoproteins

Low density lipoproteins $(\mathrm{d}=1.019-1.063 \mathrm{~kg} / \mathrm{l})$ were isolated by ultracentrifugation from the plasma of healthy donors using an established protocol (22). After isolation, low density lipoproteins were extensively dialysed against a Tris-HCl buffer ( $5 \mathrm{mmol} / \mathrm{l}, \mathrm{pH} 7.4$ ) containing $1 \mathrm{mmol} / 1$ EDTA. The cholesterol, triacylglycerol, phospholipid and protein content of the low density lipoprotein preparation were determined. Low density lipoproteins were labelled with ${ }^{125}$ I by the iodine monochloride method (23). Before modification, low density lipoproteins were dialysed against a nitrogen-saturated Tris-HCl buffer $(5 \mathrm{mmol} / \mathrm{l}$, $\mathrm{pH}$ 7.4) free of EDTA and diluted to a protein concentration of $0.1 \mathrm{~g} / \mathrm{l}$. Incubations were performed for $24 \mathrm{~h}$ in $35-\mathrm{mm}$ culture dishes with serum-free Ham's F-10 medium $(2 \mathrm{ml})$ in the presence of either polymorphonuclear leukocytes or $10 \mu \mathrm{mol} / 1$ $\mathrm{CuSO}_{4}\left(37^{\circ} \mathrm{C}, 95 \% \mathrm{O}_{2}, 5 \% \mathrm{CO}_{2}\right)$. In some incubations, cells were activated with $6.25 \mathrm{nmol} / \mathrm{l}$ phorbol 12-myristate 13-acetate (Sigma Chemical Co., St. Louis, MO, USA). Cell integrity was monitored visually by phase contrast light microscopy and trypan blue exclusion. The protease inhibitor, aprotinin $(0.1$ g/l) (Sigma Chemical Co., St. Louis, MO, USA), was added to the incubations to prevent non-specific degradation of the apolipoprotein B-100. Low density lipoproteins were acetylated with acetic anhydride and saturated sodium acetate as described (24).

\section{Analytical techniques}

The extent of lipid peroxidation in the modified low density lipoproteins was quantified by measuring thiobarbituric acidreactive substances, and expressed as malondialdehyde equivalents (8). The electrophoretic mobility of the modified low density lipoproteins was tested by agarose gel electrophoresis (25) using a commercially available kit (Lipidophor, Immuno $\mathrm{GmbH}$, Vienna, Austria). The ability of macrophages to degrade the modified low density lipoproteins was determined as follows: $10 \mu \mathrm{g}$ of ${ }^{125}$ I-labelled low density lipoproteins (native or modified) were added to macrophages in $35-\mathrm{mm}$ cell culture dishes in $1 \mathrm{ml}$ of RPMI 1640 , and incubated at $37^{\circ} \mathrm{C}$ for $5 \mathrm{~h}$. The medium was then removed and analysed for non-iodide trichloroacetic acid-soluble radioactivity as described elsewhere (24). Control dishes without macrophages were run and specific degradation was calculated by subtracting these cell-free controls from incubations in the presence of macrophages. Competition experiments were performed using a tenfold excess of unlabelled low density lipoproteins.

Protein was determined by the Lowry method (26) using serum albumin as a standard. Superoxide anion production was determined by measuring superoxide dismutase ${ }^{2}$ ) inhibitable cytochrome $c$ reduction, using the end point procedure described by Markert et al. (27). Cholesterol, triacylglycerols and phospholipids were determined by established standard methods in our routine clinical chemistry laboratory.

\section{Inhibitors}

5,8,11,14-Eicosatetraynoic acid was purchased from Cayman Chemical, Ann Arbor, MI, USA. Butylated hydroxytoluene, mannitol, catalase ${ }^{2}$ ) and superoxide dismutase were from Sigma, Chemical Co., St. Louis, MO, USA. Butylated hydroxytoluene and eicosatetraynoic acid were dissolved in ethanol while all other inhibitors were dissolved in Ham's F-10 medium (GIBCO, Paisley, UK). Inhibitors were added to the incubations in $20 \mu \mathrm{l}$ aliquots before the start of incubations. Control dishes were incubated under identical conditions but in the absence of inhibitors. Controls without cells or copper ions were also run. Superoxide dismutase was heat inactivated by incubating the enzyme at $90^{\circ} \mathrm{C}$ for $10 \mathrm{~min}$ in a shaking water bath.

\section{Statistics}

Statistical analysis was performed using the Wilcoxon test for matched päirs.

\section{.2) Enzymes}

Catalase: Hydrogen-peroxide: hydrogen-peroxide oxidoreductase (EC 1.11.1.6)

Superoxide dismutase: Superoxide : superoxide oxidoreductase (EC 1.15.1.1) 


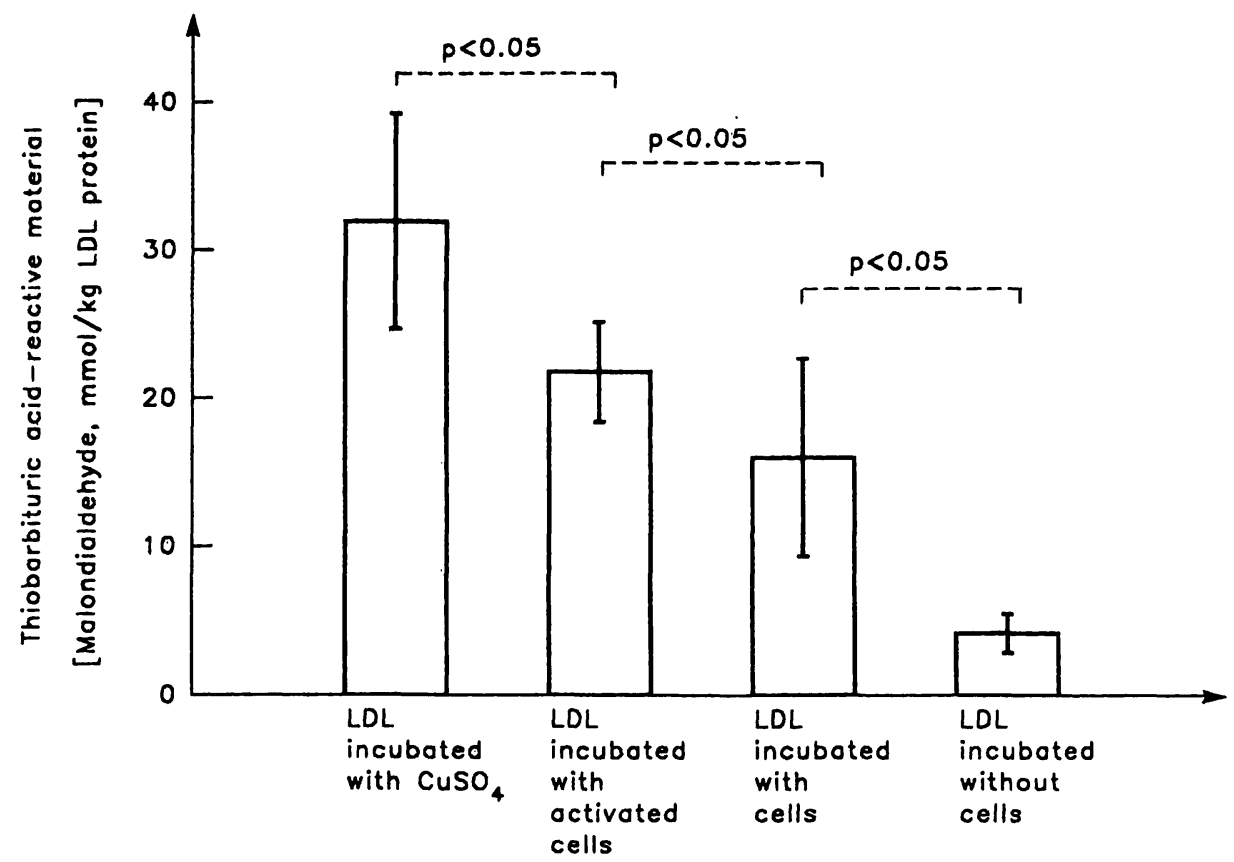

Fig. 1. Oxidation of low density lipoprotein $(\mathrm{LDL})$ preparations $(n=5)$ by copper ions, polymorphonuclear leukocytes and activated polymorphonuclear leukocytes. Cells were activated with phorbol 12-myristate 13-acetate. Experimental conditions as described in Materials and Methods.

\section{Results}

Incubation of low density lipoproteins (protein concentration $0.1 \mathrm{~g} / \mathrm{l}$ ) for $24 \mathrm{~h}$ in the presence of freshly isolated human polymorphonuclear leukocytes $\left(3 \times 10^{6}\right.$ cells per dish) produced $16.0 \pm 6.9 \mathrm{mmol}$ malondialdehyde equivalents per $\mathrm{kg}$ low density lipoprotein protein $(n=5)$, whereas control incubations without cells produced $4.2 \pm 1.4 \mathrm{mmol}$ malondialdehyde equivalents per $\mathrm{kg}$ low density lipoprotein $(\mathrm{n}=5 ; \mathrm{p}<0.05)$. Lipid peroxidation was dependent on the cell number: $5 \times 10^{5}$ polymorphonuclear leukocytes yielded $7 \mathrm{mmol}$ malondialdehyde equivalents per $\mathrm{kg}$ low density lipoprotein protein, whereas $1 \times 10^{6}$ cells yielded $9.5 \mathrm{mmol}$ malondialdehyde equivalents per $\mathrm{kg}$ low density lipoprotein. Addition of $6.25 \mathrm{nmol} / \mathrm{l}$ phorbol 12-myristate 13-acetate to $3 \times 10^{6}$ polymorphonuclear leukocytes caused a further statistically significant increase of peroxidation of low density lipoprotein lipids $(21.7 \pm 3.4 \mathrm{mmol}$ malondialdehyde equivalents per $\mathrm{kg}$ low density lipoprotein protein; $n=5 ; p<0.05$ ) (fig. 1). Acceleration of lipid peroxidation by activated cells was apparent beyond 6 hours of incubation (fig. 2). The enhanced oxidation of low density lipoprotein lipids by acti-

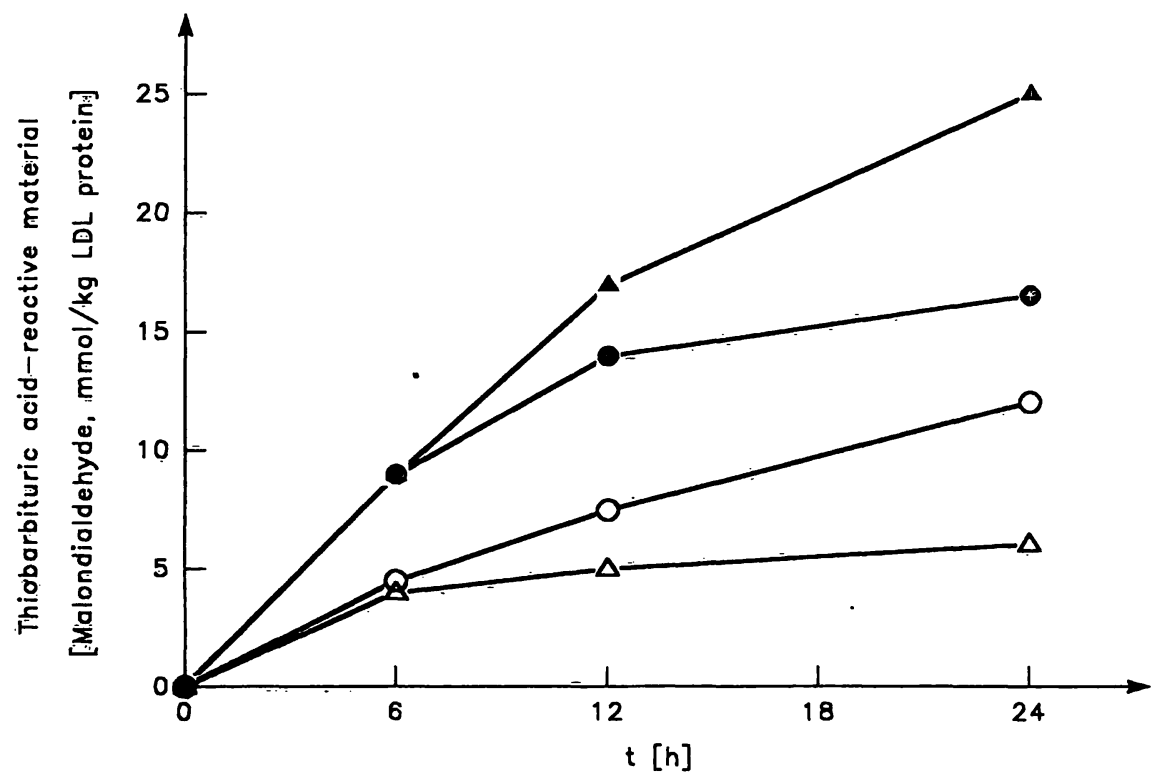

Fig. 2. Time course of thiobarbituric acid reactive substance formation during incubation of a low density lipoprotein (LDL) preparation with polymorphonuclear leukocytes (open circles), activated polymorphonuclear leukocytes (filled circles), copper ions (filled triangles), and control incubations without cells or copper ions (open triangles). Incubation conditions are as described in Materials and Methods. Mean values of duplicate determinations from one experiment. 


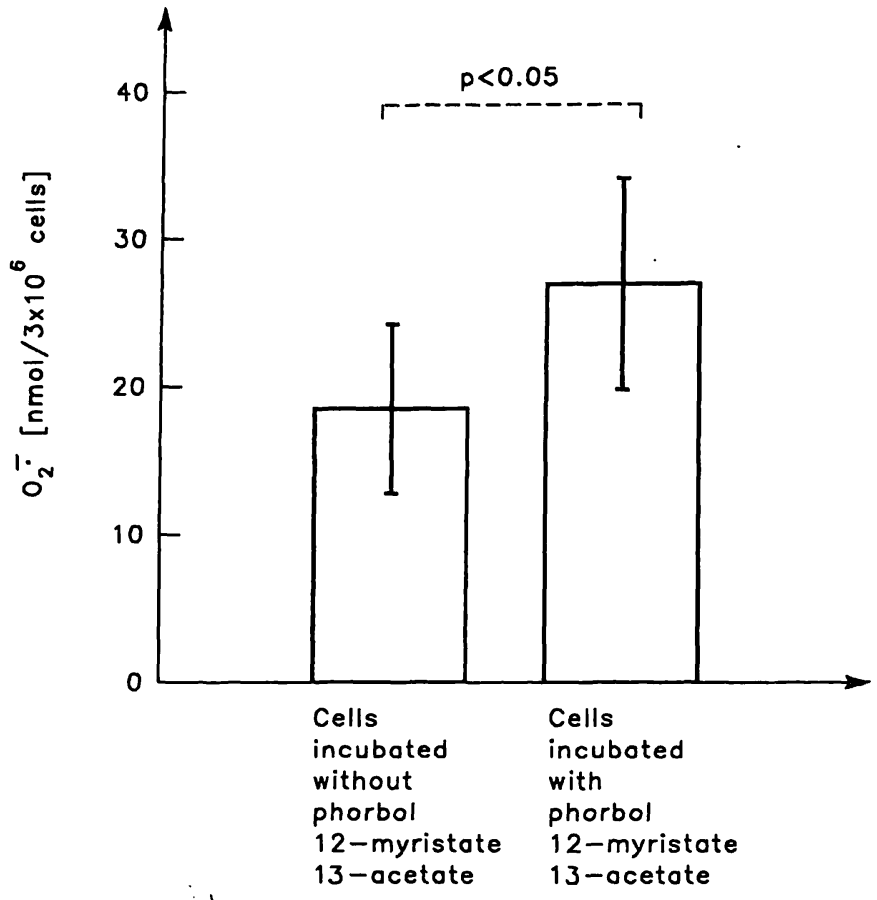

Fig. 3. Superoxide anion production by polymorphonuclear leukocytes $(n=5)$ in the presence and absence of phorbol 12-myristate 13-acetate. Experimental conditions as described in Materials and Methods.

vated polymorphonuclear leukocytes was accompanied by an increased production of superoxide anions (fig. 3).

Modification of apolipoprotein B-100 by lipid peroxidation products was shown by agarose gel electrophoresis. Low density lipoprotein particles incubated for $24 \mathrm{~h}$ in the presence of polymorphonuclear leukocytes showed an increased negative charge compared with native low density lipoprotein particles incubated without cells (fig. 4). Furthermore, macrophage degradation of low density lipoproteins modified by polymorphonuclear leukocytes was enhanced (tab. 1). The accelerated lipid peroxidation achieved by stimulation of the cells with phorbol 12-myristate 13-acetate also affected the degradation of these low density lipoprotein particles by macrophages (tab. 1). Aprotinin, which was added to prevent degradation of apolipoprotein B-100 by proteases, had no effect on the degradation of modified low density lipoproteins by macrophages (tab. 1).

Macrophage degradation of low density lipoproteins modified by polymorphonuclear leukocytes was inhibited by a 10 -fold excess of unlabelled acetyl- or copper-modified low density lipoproteins. Unlabelled acetylated low density lipoproteins and low density lipoproteins oxidized by copper ions displaced $60 \%$ and $80 \%$, respectively, of the ${ }^{125}$ I-labelled low density lipoproteins which had previously been incubated in the presence of polymorphonuclear leukocytes for $24 \mathrm{~h}$ (fig. 5).

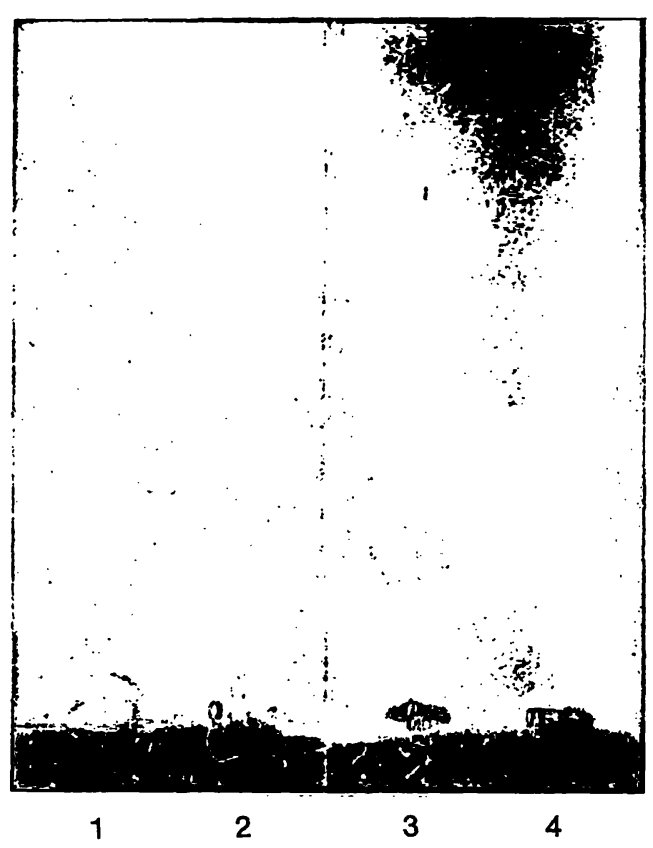

Fig. 4. Agarose gel electrophoresis of a low density lipoprotein (LDL) preparation incubated for $24 \mathrm{~h}$ in the presence of activated polymorphonuclear leukocytes (lane 1), non-activated polymorphonuclear leukocytes (lane 2), native LDL (lane 3), and LDL incubated without cêlls (lane 4). Incubation conditions as described in Materials and Methods.

The effect of various inhibitors and radical scavengers on the oxidation of low density lipoproteins by polymorphonuclear leukocytes is shown in table 2 . Addition of $30 \mathrm{kU} / \mathrm{l}$ superoxide dismutase resulted in a marked inhibition of peroxidation of low density lipoprotein lipids in both activated and non-activated

Tab. 1. Macrophage degradation of a low density lipoprotein (LDL) preparation previously incubated in the presence of polymorphonuclear leukocytes

Sample

n Degradation by macrophages

$(\mathrm{g} / 5 \mathrm{~h} \cdot \mathrm{kg}$

cell protein)

LDL incubated in the absence of cells

$7 \quad 0.30 \pm 0.07$

LDL incubated in the presence of $\mathrm{CuSO}_{4}$

$51.40 \pm 0.11^{*}$

LDL incubated in the presence

$31.36-1.43^{*+}$

of $\mathrm{CuSO}_{4}$ and aprotinin

LDL incubated in the presence of cells and aprotinin

$7 \quad 0.98 \pm 0.23^{*}$

LDL incubated in the presence of activated cells plus aprotinin

$7 \quad 1.29 \pm 0.35^{* *}$

Values are means \pm SD or range $\left({ }^{+}\right)$from the indicated number of experiments. For cell activation, phorbol 12-myristate 13acetate was used as described in Materials and Methods.

* Significantly different from low density lipoproteins incubated in the absence of cells $(p \leqslant 0.05)$

** Significantly different from lowi density lipoproteins incubated in the presence of cells and aprotinin without phorbol myristate acetate $(\mathrm{p}<0.05)$ 


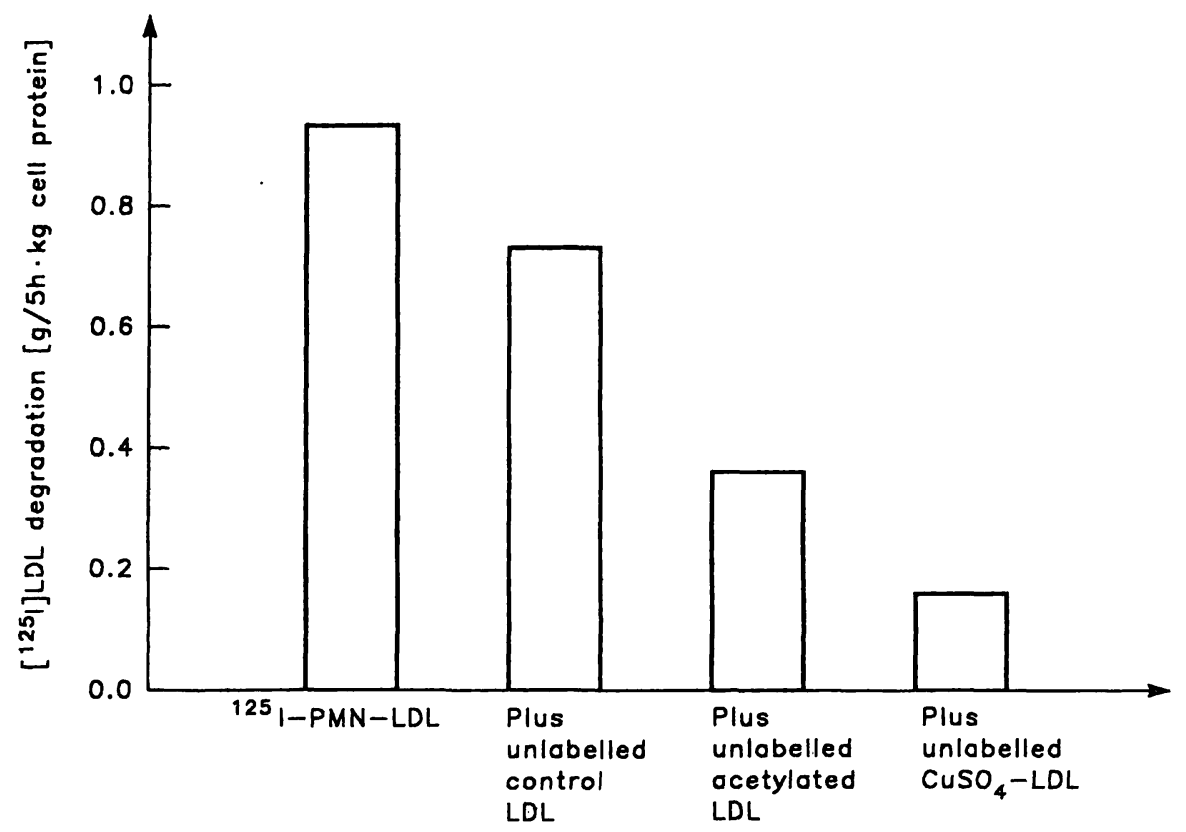

Fig. 5. Macrophage degradation of a labelled low density lipoprotein preparation previously incubated in the presence of polymorphonuclear leukocytes ( ${ }^{125} \mathrm{I}-\mathrm{PMN}-\mathrm{LDL}$ ). Displacement by unlabelled LDL incubated without cells (control LDL), by unlabelled acetylated LDL, or by unlabelled LDL previously incubated in the presence of copper ions (CuSO $\left.{ }_{4}-\mathrm{LDL}\right)$. Experimental conditions as described in Materials and Methods. Mean values of duplicate determinations from one experiment.

cells. Most of the inhibitory effect was abolished after heating of the enzyme to $90^{\circ} \mathrm{C}$ for $10 \mathrm{~min}$. Similar effects were observed with $40 \mu \mathrm{mol} / 1$ of the nonspecific general antioxidant, butylated hydroxyto-

Tab. 2. Effect of different inhibitors on the oxidation of a low density lipoprotein (LDL) preparation by polymorphonuclear leukocytes.

\begin{tabular}{|c|c|c|}
\hline \multirow[t]{2}{*}{ Inhibitor added } & \multicolumn{2}{|c|}{$\begin{array}{l}\text { Thiobarbituric } \\
\text { acid-reactive materials } \\
\text { (Malondialdehyde, } \\
\text { mmol/kg LDL protein) }\end{array}$} \\
\hline & $\begin{array}{l}\text { Cells } \\
\text { plus LDL }\end{array}$ & $\begin{array}{l}\text { Activated } \\
\text { cells } \\
\text { plus LDL }\end{array}$ \\
\hline No inhibitor & 10.3 & 18.4 \\
\hline $\begin{array}{l}\text { Butylated hydroxytoluene } \\
(40 \mu \mathrm{mol} / \mathrm{l})\end{array}$ & 1.6 & 1.8 \\
\hline $\begin{array}{l}\text { Superoxide dismutase } \\
(30 \mathrm{kU} / \mathrm{l})\end{array}$ & 1.8 & 6.0 \\
\hline $\begin{array}{l}\text { Superoxide dismutase } \\
\text { (heat inactivated) }\end{array}$ & n.d. & 14.1 \\
\hline Catalase $(110 \mathrm{kU} / \mathrm{l})$ & n.d. & 16.9 \\
\hline $\begin{array}{l}\text { Eicosatetraynoic acid } \\
(20 \mu \mathrm{mol} / \mathrm{l})\end{array}$ & 8.7 & 17.4 \\
\hline Mannitol (25 mmol/l) & 10.0 & 18.2 \\
\hline
\end{tabular}

LDL incubated without

cells and without

2.2

inhibitor

Values are means of duplicate determinations from one representative experiment. For cell activation, phorbol 12-myristate

13-acetate was used as described in Materials and Methods. n. d. = not determined. luene. The lipoxygenase inhibitor, eicosatetraynoic acid, was without effect on the oxidation of low density lipoproteins by human polymorphonuclear leukocytes, as was catalase $(110 \mathrm{kU} / \mathrm{l})$ and the hydroxyl radical scavenger, mannitol $(25 \mathrm{mmol} / \mathrm{l})$.

\section{Discussion}

Oxidative modification of low density lipoproteins has been implicated in the generation of macrophagederived foam cells $(7-12)$, a hallmark of the early atherosclerotic lesion $(14,24)$. Once the endothelial lining of the vessel wall has been damaged, the progression of atherosclerosis can be considered as a chronic inflammatory process (13).

Polymorphonuclear leukocytes are found in the subendothelial space at sites of arterial damage in experimental animals (13). These cells contain lipoxygenase enzymes and release oxygen radicals upon encounter with an appropriate ligand $(15,19)$. They have been shown to oxidize low density lipoprotein lipids, making them cytotoxic (17), and to alter low density lipoproteins by the action of elastase, resulting in their increased uptake by macrophages via the classical low density lipoprotein receptor (20). In contrast, our results show that incubation of low density lipoproteins with human polymorphonuclear leukocytes leads to oxidatively modified low density lipoproteins which are recognized by the scavenger receptor of macrophages. Scavenger receptor-mediated uptake of modified low density lipoproteins must be considered more important for the development of artheroscler- 
otic plaques in vivo, since monocytes lose most of their low density lipoprotein receptor activity upon transformation to macrophages, which then express scavenger receptor activity (24). The observation that low density lipoproteins modified by human polymorphonuclear leukocytes are displaced less efficiently by acetylated low density lipoproteins than by low density lipoproteins modified by copper ions, confirms findings of Sparrow et al. concerning the heterogeneity of the scavenger receptor with respect to different ligands (28).

The present investigations strongly suggest a role of superoxide anions in the oxidative modification of low density lipoproteins by polymorphonuclear leukocytes and exclude a lipoxygenase-mediated oxidation mechanism for the following reasons:

i) oxidation of low density lipoproteins was inhibited by superoxide dismutase

ii) eicosatetraynoic acid was without effect on the oxidation of low density lipoproteins

iii) stimulation of superoxide anion release increased the modification of low density lipoproteins

Phorbol 12-myristate 13-acetate is a direct activator of protein kinase $\mathrm{C}$ and therefore selectively stimulates the formation of superoxide anions. It bypasses the activation of eicosanoid formation in human polymorphonuclear leukocytes (29).

This mechanism of low density lipoprotein modification in polymorphonuclear leukocytes is in contrast to macrophages and endothelial cells where 15-lipoxygenase activity has been suggested to be responsible for the oxidative modification of low density lipoproteins $(11,12)$.

Abdalla et al. (18) reported peroxidation of low density lipoprotein lipids by polymorphonuclear leukocytes activated with substances which are known to increase leukotriene production (29). However, they did not employ lipoxygenase inhibitors to exclude a contribution of lipoxygenase enzymes to the modification of low density lipoproteins by human polymorphonuclear leukocytes. The authors emphasized the requirement for iron to initiate peroxidation of low density lipoprotein lipids. In their system, however, containing activated polymorphonuclear leukocytes and ferritin, they generated mainly lipid hydroperoxides, with only very small quantities of aldehydes which are required for the modification of the apolipoprotein B-100 and therefore for foam cell formation (9). We used the protocol originally published by Henriksen et al. (30) to oxidize low density lipoproteins; this protocol uses the iron-containing Ham's F-10 cell culture medium. With his approach we were able to generate 10 times more malondialdehyde equivalents than reported by Abdalla et al. (18). Since catalase and mannitol did not influence the oxidative modification of low density lipoproteins by polymorphonuclear leukocytes it is unlikely that other reactive oxygen species such as hydrogen peroxide or hydroxyl radicals contribute to the oxidation process.

Oxidation of low density lipoproteins by polymorphonuclear leukocytes was observed even in the absence of a stimulus. Nathan reported that the adhesion of polymorphonuclear leukocytes to plastic surfaces is sufficient to activate polymorphonuclear leukocytes at a low rate (31). This is supported by the present investigation using adherent cells for low density lipoprotein modification, which had already generated superoxide anions at a low rate in the absence of a stimulus.

It is concluded that an increase in the release of superoxide anion from polymorphonuclear leukocytes, as may occur at lesion sites in vivo, can accelerate oxidative modification of low density lipoproteins. Possible activators in vivo are immune complexes (32). Autoantibodies directed against oxidatively modified low density lipoproteins have recently been reported in vivo (33). Therefore, polymorphonuclear leukocytes may contribute to foam cell formation in vivo as do other cells found in atherosclerotic lesions, such as endothelial cells, macrophages, smooth muscle cells, and monocytes.

\section{Acknowledgement}

We thank Mrs. C. Wiese, A. Rudolph and U. Bonitz for expert technical assistance. 


\section{References}

1. Kannel, W. B., Castelli, W. P. \& Gordon, T. (1979) Cholesterol in the prediction of atherosclerotic disease. New pcrspectives based on the Framingham Study. Ann. Intern. Med. 90, 85-91.

2. Lipid Research Clinics Program (1984) The Lipid Research Clinics Coronary' Primary Prevention Trial Result. Reduction in incidence of coronary heart disease. J. Am. Med. Ass. $251,351-364$.

3. Anitschkow, N. (1913) Über die Veränderungen der Kaninchenaorta bei experimenteller Cholesterinsteatose. Beitr. Pathol. Anat. Allg. Pathol. 56, 379-404.

4. Wissler, R. W. \& Vesselinovitch, D. (1968) Experimental models of human atherosclerosis. Ann. N. Y. Acad. Sci. 149, 907-922.

5. Windaus, A. (1910) Über den Gehalt normaler und atheromatöser Aorten an Cholesterin und Cholesterinestern. Hoppe-Seyler's Z. Physiol. Chem. 67, 174-176.

6. Zilversmit, D. B. (1968) Cholesterol flux in the atherosclerotic plaque. Ann. N. Y. Acad. Sci. 149, 710-724.

7. Steinberg, D., Parthasarathy, S., Carew, T., Khoo, J. C. \& Witztum, J. L. (1989) Beyond cholesterol. Modifications of low density lipoprotein that increases its atherogenicity. N. Engl. J. Med. 320, 915-924.

8. Steinbrecher, U. P., Parthasarathy, S., Leake, D. S., Witztum, J. L. \& Steinberg, D. (1984) Modification of low density lipoprotein by endothelial cells involves lipid peroxidation and degradation of low density lipoprotein phospholipids. Proc. Natl. Acad. Sci. USA 81, 3883-3887.

9. Steinbrecher, U. P. (1987) Oxidation of low density lipoprotein results in derivatization of lysine residues of apolipoprotein B by lipid peroxide decomposition products. J. Biol. Chem. 262, 3603-3608.

10. Steinbrecher, U. P. (1988) Role of superoxide in endothelialcell modification of low-density lipoproteins. Biochim. Biophys. Acta 959, 20-30.

11. Parthasarathy, S., Wieland, E. \& Steinberg, D. (1989) A role for endothelial cell lipoxygenase in the oxidative modification of low density lipoprotein. Proc. Natl. Acad. Sci. USA 86, 1046,-1050.

12. Rankin, S., Parthasarathy, S. \& Steinberg, D. (1991) Evidence for a dominant role of lipoxygenase(s) in the oxidation of LDL by mouse peritoneal macrophages. J. Lipid. Res. 32, 449-456.

13. Hagihara, H., Nomoto, A., Mutoh, S., Yamaguchi, I. \& Ono, T. (1991) Role of inflammatory responses in initiation of atherosclerosis: Effects of anti-inflammatory drugs on cuff-induced leukocyte accumulation and intimal thickening of rabbit carotid artery. Atherosclerosis 91, 107-116.

14. Aqel, N. M., Ball, R. Y., Waldmann, H. \& Mitchinson, M. J. (1984) Monocyte origin of foam cells in human atherosclerotic plaques. Atherosclerosis 53, 265-271.

15. Babior, B. M. (1984) The respiratory burst of phagocytes. J. Clin. Invest. $73,599-601$.

16. Ludwig, P. W., Hunninghake, D. B. \& Hoidal, J. R. (1982) Increased leucocyte oxidative metabolism in hyperlipoproteinemia. Lancet 2, 348-350.

17. Cathçart, M. K., Morel, D. W. \& Chisolm, G. M. (1985) Monocytes and neutrophils oxidize low density lipoprotein, making it cytotoxic. J. Leưkocyte Biol. 38, 341-350.

18. Abdalla, D. S. P., Campa, A. \& Monteiro, H. P. (1992) Low density lipoprotein oxidation by stimulated neutrophils and ferritin. Atherosclerosis 97, 149-159.

19. Soberman, R. J., Harper, T. W., Bettridge, D., Lewis, R. A. \& Austen, K. F. (1985) Characterization and separation of the arachidonic acid 5-lipoxygenase and linoleic acid $\omega$ 6 lipoxygenase (arachidonic acid 15-lipoxygenase) of human polymorphonuclear leucocytes. J. Biol. Chem. 260, $4508-4515$.
20. Polacek, D., Byrne, R. E. \& Scanu, A. M. (1988) Modification of low density lipoproteins by polymorphonuclear cell elastase leads to enhanced uptake by human monocytederived macrophages via the low density lipoprotein receptor pathway. J. Lipid. Res. 29, 797-808.

21. Boyum, A. (1976) Isolation of lymphocytes, granulocytes and macrophages. Scand. J. Immunol. Suppl. 5, 9-15.

22. Havel, R. J., Eder, H. A. \& Bragdon, J. H. (1955) The distribution and chemical composition of ultracentrifugally separated lipoproteins in human serum. J. Clin. Invest. 43 , 1345-1353.

23. Bilheimer, D. W., Goldstein, J. L., Grundy, S. M. \& Brown, M. S. (1975) Reduction in cholesterol and low density lipoprotein synthesis after portacaval shunt surgery in a patient with homozygous familial hypercholesterolemia. J. Clin. Invest. 56, 1420-1430.

24. Goldstein, J. L., Ho, Y. K., Basu, S. K. \& Brown, M. S. (1979) Binding site on macrophages that mediates uptake and degradation of acetylated low density lipoprotein, producing massive cholesterol deposition. Proc. Natl. Acad. Sci. USA 76, 333-337.

25. Seidel, D., Wieland, H. \& Ruppert, C. (1973) Improved techniques for assessment of plasma lipoprotein patterns. I. Precipitation in gels after electrophoresis with polyanionic compounds. Clin. Chem. 19, 737-739.

26. Lowry, O. H., Rosebrough, N. J., Farr, A. L. \& Randall, R. J. (1951) Protein measurement with the Folin phenol reagent. J. Biol. Chem. 193, 265-275.

27. Markert, M., Andrews, P. C. \& Babior, B. M. (1984) Measurement of $\mathrm{O}_{2}^{-}$production by human neutrophils. The preparation and assay of NADPH oxidase-containing particles from human neutrophils. Meth. Enzymol. 105, 358365.

28. Sparrow, C. P., Parthasarathy, S. \& Steinberg, D. (1989) A macrophage receptor that recognizes oxidized low density lipoprotein but not acetylated low density lipoprotein. J. Biol. Chem. 264, 2599-2604.

29. Haurand, M. \& Flohé, L. (1989) Leukotriene formation by human polymorphonuclear leukocytes from endogenous arachidonate. Physiological triggers and modulation by prostanoids. Biochem. Pharmacol. 38, 2129-2137.

30. Henriksen, T., Mahoney, E. M. \& Steinberg, D. (1981) Enhanced macrophage degradation of low density lipoprotein previously incubated with cultured endothelial cells: Recognition by receptors for acetylated low density lipoproteins. Proc. Natl. Acad. Sci. USA 78, 6499-6503.

31. Nathan, C. F. (1987) Neutrophil activation on biological surfaces. Massive secretion of hydrogen peroxide in response to products of macrophages and lymphocytes. J. Clin. Invest. 80, 1550-1560.

32. Brunkhorst, B. A., Strohmeier, G., Lazzari, K., Weil, G., Melnick, D., Fleit, H. B. \& Simons, E. R. (1992) Differential roles of Fc gamma RII and Fc gamma RIII in immune complex stimulation of human neutrophils. J. Biol. Chem. 267, 20659-20666.

33. Palinski, W., Rosenfeld, M. E., Ylä-Herttuala, S., Gurtner, G. C., Socher, S. S., Butler, S. W., Parthasarathy, S., Carew, T. E., Steinberg, D. \& Witztum, J. L. (1989) Low density lipoprotein undergoes oxidative modification in vivo. Proc. Natl. Acad. Sci. USA 86, 1372-1376.
Dr. Eberhard Wieland
Georg-August-Universität Göttingen
Zentrum Innere Medizin
Abteilung Klinische Chemie
Robert-Koch-Straße 40
D-37070 Göttingen
Germany 
